\title{
PENTINGNYA MEMBANGUN KOLEKTIFITAS (KEBERSAMAAN)
}

\begin{abstract}
Oleh: M. Jamil ${ }^{1}$
Hiduplah kamu bersama manusia sebagaimana pohon yang berbuah, mereka melemparinya dengan batu, tetapi ia membalasnya dengan buah.

Seperti yang kita ketahui bersama bahwasannya kolektifitas merupakan sikap yang tertanam dalam diri pribadi seseorang yang memiliki rasa kebersamaan dalam melalukan segala sesuatu, baik bernilai positif atau negatif. Maksud dalam tulisan kali ini, yaitu mengandung pentingnya membangun suatu kebersamaan agar tercapai suatu tujuan yang baik atau suatu tujuan yang bernilai positif.

Pada dasarnya manusia adalah makhluk sosial yang tidak bisa hidup sendiri dalam kehidupan bermasyarakat, berbangsa dan bernegara. Manusia tersebut pasti memerlukan suatu kebersamaan atau bantuan dari seseorang untuk melakukan sesuatu yang ingin dicapai, walau ada juga sebagian yang bisa dilakukan sendiri namun dalam suatu kehidupan pasti lebih banyak suatu kebutuhan untuk memenuhi tuntutan hidupnya memerlukan bantuan dari orang lain.

Dalam suatu remaja, pemuda/mahasiswa, maupun masyarakat pada umumnya, nilai kebersamaan dewasa ini sangatlah kurang. Terbukti dari tindakan segala sesuatu semata karena ingin mengunggulkan diri mereka, kelompok mereka, organisasi mereka, dan lain sebagainya. Itulah keegoisan yang telah tertanam membatu dalam pribadi seseorang atau suatu kelompok. Sejatinya sikap demikian harus dihindari bahkan kita harus dihilangkan agar dalam setiap gerak

\footnotetext{
${ }^{1}$ Ketua Umum Pusat Studi Mahasiswa Pascasarjana (PUSMAJA) Mbojo-Yogyakarta Periode 2015-2017 | | Ketua II Bagian Eksternal Dewan Pimpinan Cabang Perhimpunan Mahasiswa Hukum Indonesia Daerah Istimewa Yogyakarta (DPC PERMAHI DIY) Periode 2012-2014 | Email: jamilncera@gmail.com | FB/Youtube/IG/Twitter: @MJAMILSH | Website: http://www.mjamil.my.id.
} 
gerik langkah kita terbangun rasa kebersamaan dalam setiap segi hidup dan kehidupan bermasyarat, berbangsa dan bernegara.

\section{Kebersamaan di Masa Remaja}

Masa remaja adalah masa yang berapi-api, masa dimana sangat mudah untuk dipengaruhi pola pikir dan tingkahnya. Pada masa remaja pola pikirnya masih labil. Apapun yang ditransfer atau yang telah dia amati akan menjadi patokan dalam berpikir dan bertindak. Jika yang diamati atau diperoleh dalam pergaulan, di suatu lembaga formal pendidikan, atau yang diperolehnya dari tokoh panutan masyarakat merupakan sesuatu yang baik (nilai moral, kebersamaan, kesederhanaan, menghargai, budi pekerti, kerja keras, tanpa pamrih, rendah hati, suka menolong, dll), maka itulah yang akan menjadi landasan berpikirnya (mind set). Demikian pula sebaliknya jika yang mereka peroleh dalam kesehariannya adalah suatu kejanggalan perilaku (berkelahi, berjudi, minum-minuman beralkohol, berzina dll), maka yang demikian akan menjadi mind set-nya pula.

Terkadang, ada anggapan bahwa perilaku tidak senonoh merupakan perilaku yang wajar baginya karena itu merupakan cerminan dari apa yang mereka lihat dan amati dalam pergaulan. Parahnya, mind set mereka sudah tertanam bahwa tindakan demikian sebagai bentuk pengakuan diri bahwa mereka hadir dan ada. Dan itu butuh pengakuan dengan cara-cara yang tak wajar menurut etika dan norma masyarakat, namun hal yang lumrah baginya. Tak peduli, tindakan itu berdampak buruk atau tidak bagi dirinya dan orang lain.

Membangun pola pikir (mind set) remaja agar mempunya rasa atau keinginan untuk bersama-sama dalam hal kebaikan, perlu ada dorongan atau didikan dari berbagai pihak, baik didikan dalam rumah tangga, didikan lingkungan sekolah, maupun didikan dari lingkungan masyarakat pada umunya.

Didikan di rumah tangga yang diperankan orang tua, memberikan pemahaman dasar pada anak-anaknya agar nilai religius dan pentingnya membangun kebersamaan bila berada dalam suatu lingkungan tertanam dengan baik dalam pribadi dan tingkah laku anak-anaknya. Didikan di lingkungan sekolah yang dilakoni para guru, sepatutnya mendidik anak-anak didiknya dengan hati. Mendidik dengan hati akan melunakkan kekerasan yang dominan diperankan 
kaum remaja. Apabila seorang guru mendidik dengan hati, sekeras atau sebandel apapun anak didiknya dalam lingkup sekolah, maka akan luluh dengan didikan hati seorang guru yang penuh kasih sayang. Pada dasarnya remaja ingin mendapatkan transferan ilmu dari para gurunya dengan cara yang lebih santun dan penuh kesabaran, dengan harapan anak remaja mampu menyerap dengan indah apa-apa yang guru sampaikan dan selalu mereka ingat pancaran nilai-nilai tersebut sampai kapan pun dan dimanapun.

Didikan masyarakat, melibatkan semua unsur masyarakat. Remaja, seberapa bandel pun mereka, pastilah ada keinginan dalam hatinya mengambil bagian dalam kehidupan bermasyarakat. Tinggal diarahkan melalui apa yang mereka bisa dan apa yang mereka mampu lakukan.

Seorang tokoh masyarakat yang mempunyai ilmu tentang keagamaan (guru ngaji) misalnya, dapat memainkan peran didikan bagi remaja untuk mengajarkan bagaimana membaca Al-Qur'an dengan baik dan benar. Kontribusi guru ngaji sangan besar dalam suatu masyarakat kita, karena kemurahan hati dan kegigihan mereka mengajarkan baca Al-Qur'an kepada remaja-remaja dalam suatu masyarakat sangat besar. Buah kegigihan mereka jualah, banyak remaja yang sudah mahir mengaji.

Dalam suatu masyarakat, perlu juga membangun suatu wadah pemersatu bagi remaja yang berada dalam suatu masyarakat. Wadah tersebut dapat berupa komunitas atau organisasi remaja. Para orang tua dan tokoh masyarakat hanya perlu mengarahkan, terutama dalam agenda-agenda yang mereka lakukan yaitu agenda-agenda yang bisa membangkitkan rasa persaudaraan mereka sesama remaja. Misalnya, jika ada Pekerjaan Rumah (PR) dari sekolah, para remaja dapat mengerjakannya secara bersama melalui organisasi remaja yang mereka bentuk.

Bila ada suatu penyelesaian soal-soal atau pekerjaan rumah tersebut dirasa sulit untuk dikerjakan sendiri, disitulah wadah untuk mendiskusikan semua persoalan-persoalan yang dihadapi, karena seberapa besarpun suatu persoalan kalau dikerjakan secara bersama maka akan terasa mudah. Begitu juga sebaliknya, sesederhana apa pun suatu pekerjaan kalau dikerjakan sendirian akan terasa sulit adanya. Seperti halnya sapu lidi. Sapu lidi merupakan gabungan dari puluhan atau 
ratusan lidi. Jika satu lidi dipakai untuk menyapu batu sebesar genggaman tangan, maka patahlah ia karena satu lidi punya tingkat kerapuhan yang tinggi. Sebaliknya, jika batang lidi-lidi tersebut digabungkan jadi satu dalam satu ikatan akan menjadi sapu lidi dan juga akan bisa menyapu batu yang besarnya sebesar genggaman tangan tersebut. Oleh karena itu, makna atau hasil yang didapat dari suatu kebersamaan itu akan bernilai tinggi adanya.

\section{Kebersamaan Pemuda/Mahasiswa}

Pemuda/mahasiswa merupakan agen pengontrol (agent of control) dan agen perubahan (agent of change). Di tangan pemuda/mahasiswa bisa membuat atau menciptakan suatu perubahan dalam suatu lingkup masyarakat, bangsa, negara, bahkan dunia. Sifat dan karakter mahasiswa yang sejatinya masih murni dari kendali atau pengaruh siapapun (independent), dengan kemurnian hati dan pikiran seorang mahasiswa bisa merangkul dari aspirasi semua kalangan, lebihlebih untuk kepentingan masyarakat menengah ke bawan. Bahkan seorang Soekarno pernah berkata "berikan saya sepuluh pemuda, maka saya akan bisa mengguncangkan dunia".

Itulah sejatinya prestasi yang akan diraih oleh pemuda/mahasiswa bilamana mereka menyatukan ide, pikiran, gagasan, dan bersama-sama melangkah melakukan perubahan untuk masyarakat, bangsa dan negara tercinta ini, maka suatu perubahan yang nyata akan terlihat atau terpampang dengan jelas dari buah tangan atau karya pemuda/mahasiswa.

Seperti halnya masyarakat Desa Ncera yang memiliki banyak pemudanya yang melanjutkan studi ke jenjang perguruan tinggi. Hampir 90\% remaja yang telah lulus SMA melanjutkan studi ke jenjang perguruan tinggi, bahkan orang yang telah berkeluarga merasa terpanggil hatinya berkeinginan mengambil bagian untuk melanjutkan studi. Di lihat dari sebaran daerah tujuan studi sangat beragam, ada yang tetap di tanah kelahiran (kabupaten/kota Bima), ada juga yang merantau lebih jauh ke Lombok, Mataram, Bali, Semarang, Malang, Surabaya, Bandung, Jakarta, Bogor, Depok, Tangerang, Bekasi, Kalimantan, kota Gudeg Yogyakarta, dan bahkan di luar negeri. 
Sudah menjadi rutinitas tiap tahunnya, bila mendekati liburan panjang kuliah, para mahasiswa-mahasiswi yang berasal dari desa Ncera yang kuliah diberbagai penjuru kota di Indonesia, mereka yang tergabung dalam organisasi daerah. Di Mataram mereka berkumpul bersama menyatukan ide dan pikiran mereka dan merencanakan terkait program yang akan mereka laksanakan di kampung halaman nanti bila musim libur panjang kuliah tiba, begitu juga yang dilakukan oleh mahasiswa-mahasiswi Ncera yang berada di Makasar, Jakarta, Yogyakarta, dan kota-kota lainnya. Masing-masing kota mempunyai program kerja yang dilaksanakan untuk kebaikan tanah kelahiran.

Tak sedap rasanya kegiatan mereka dilakukan berjalan sendiri-sendiri. Sikap demikian menunjukkan pada masyarakat bahwa mahasiswa yang notabene kalangan muda terlihat tidak kompak dan satu pikiran. Sikap dan tindakan demikian layaknya dicari jalan bersama agar pandangan masyarakat dalam melihat gerak gerik pemuda/mahasiswa menyatu dalam satu kesatuan dan bingkai kebersamaan yang utuh.

Sikap demikian bukanlah tidak bagus, hanya tidak indah dipandang karena terlihat tidak adanya kekompakan pada semua elemen pemuda/mahasiswa. Sudah saatnya semua elemen pemuda/mahasiswa tersebut duduk bersama menyatukan ide, pikiran, gagasan, dan dijalankan secara bersama-sama. Tidak ada lagi mengatasnamakan organisasi dan melaksanakan kegiatan tanpa koordinasi dan kebersamaan seluruh unsur pemuda dan mahasiswa. Mari kita bersama menyatu dengan indah layaknya lidi-lidi yang berserakan dikumpulkan jadi satu, membentuk satu kekuatan yang utuh, yaitu kekuatan untuk membangun suatu masyarakat, bangsa dan negara. Malu rasanya sikap dan sifat individual seperti itu dipertahankan, terlebih mengingat kiprah sejarah pemuda/mahasiswa tahun 1998 yang kala itu berhasil menumbangkan rezim lalim berkat kekuatan dari kebersamaan dan persaudaraan yang menyatu.

\section{Kebersamaan dalam Masyarakat}

Hidup dan kehidupan dalam bermasyarakat syarat akan nilai kebersamaan. Itulah sejatinya hidup dalam bermasyarakat yang telah menjadi 
tradisi dari masa ke masa sejak ribuan tahun silam. Kebersamaan tersebut terpatri melalui nilai-nilai yang tertanam dalam pribadi-pribadi masyarakat. Di antaranya gotong royong, musyawarah mufakat, dan senasib sepenanggungan, ramah tamah, dll. Dalam suatu masyarakat syarat akan rasa gotong royong yang tinggi, sebagai contoh, bila mana ada suatu pembangunan untuk keperluan bersama, maka masyarakat yang berada disekitar berbondong-bondong datang dan mengekspresikan rasa kebersamaan mereka dengan bentuk yang mereka bisa.

Pembangunan masjid misalnya masyarakat terbiasa berbondong-bondong datang untuk melakukan apa yang mereka bisa, ada yang menyumbangkan ide, gagasan, tenaga, atau menyumbangkan sejumlah uang untuk pembangunan tersebut. Begitupun halnya jika ada persoalan dalam suatu kehidupan bermasyarakat, maka musyawarah mufakat haruslah dikedepankan.

Itulah sikap-sikap kolektifitas yang harus tertanam dalam hidup dan kehidupan dalam suatu masyarakat. Tatkala kita ingin menggapai tujuan yang mulia sejatinya kita harus melaksakan tujuan tersebut secara bersama-sama agar suatu persoalan sesulit apapun dapat diselesaikan secara bersama-sama. Semoga penggalan tulisan ini menjadi bahan bacaan untuk kita renungkan bersama-sama bahwasannya nilai kebersamaan (kolektifitas) sangatlah tinggi manfaat dan kegunaan yang bisa didapat dalam menggapai tujuan mulia.

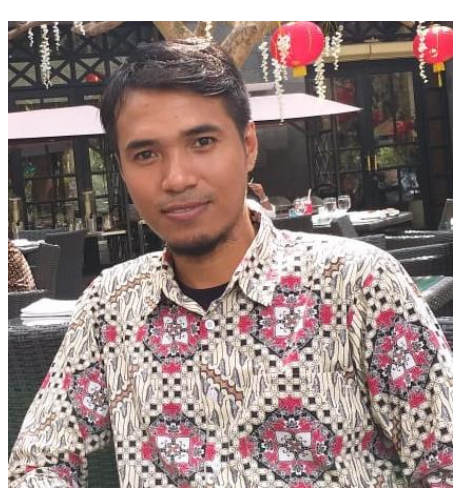

Penulis: M. Jamil, S.H.

Ketua Umum Pusat Studi Mahasiswa Pascasarjana (PUSMAJA) Mbojo-Yogyakarta Periode 2015-2017 | Ketua II Bagian Eksternal Dewan Pimpinan Cabang Perhimpunan Mahasiswa Hukum Indonesia Daerah Istimewa Yogyakarta (DPC PERMAHI DIY) Periode 2012-2014 
"Pentingnya Membangun Kolektifitas (Kebersamaan)"

\section{Ful Sumber Tulisan:}

M. Jamil, "Pentingnya Membangun Kolektifitas (Kebersamaan)", Majalah NUSANTARA IKPMDI-Yogyakarta, diterbitkan melalui Dinas Pendidikan Pemuda dan Olahraga (Disdikpora) Daerah Istimewa Yogyakarta, edisi Mei-Juni 2014, lihat Halaman 16-18. 